\title{
Larvae of Pocillopora damicornis (Anthozoa) settle and metamorphose in response to surface-biofilm bacteria
}

\author{
Cawa Tran*, Michael G. Hadfield \\ Kewalo Marine Laboratory, University of Hawaii at Manoa, 41 Ahui Street, Honolulu, Hawaii 96813, USA
}

\begin{abstract}
Larvae of the scleractinian coral Pocillopora damicornis require a natural cue from surface-biofilm bacteria to select a suitable substratum on which to attach, metamorphose, and grow into a benthic polyp. In this study, bacteria were isolated from various reef surfaces, including different species of corals and algae, and glass slides that had been placed in the field for 1 to 2 mo. Settlement assays were conducted on monospecific biofilms of bacteria isolated from the field. Of 52 different isolates, 3 showed strongly inductive capacity, whereas the others were moderately to non-inductive. The isolates were identified by sequencing their 16S rRNA genes, and their phylogenetic relationships were then analyzed. There was no correlation between the inductive capacities of individual bacterial species and their phylogenetic relationships nor between their inductive capacities and the surfaces from which they were isolated. Varying the biofilm densities affected settlement only by a strongly inductive bacterial species. Different bacterial species may also affect the inductive capacities of other species when combined. The new data provided here broaden our understanding of the roles of bacteria in the recruitment of coral larvae.
\end{abstract}

KEY WORDS: Larval settlement - Metamorphosis - Biofilm • Marine bacteria · Coral planula • Pocillopora damicornis

\section{INTRODUCTION}

The life cycle of most benthic marine invertebrates involves 2 major stages: a planktonic larval stage that allows dispersal and habitat selection, and a sessile juvenile-adult stage that results from larval settlement. Settlement involves a change in habitat during which larvae enter the juvenile environment and attach to a substratum. This is followed by metamorphosis - the rapid change in morphology that includes the loss of larval structures and gain of juvenile structures (Hadfield et al. 2001). Metamorphosis of marine invertebrate larvae is governed by a combination of biological, physical, and chemical factors (Crisp 1974). Larvae gain the ability to settle and metamorphose when they become 'competent,' which is defined as having the capacity to detect and respond to a specific environmental cue (Hadfield \& Paul 2001, Hadfield et al. 2001).
A common substratum for the settlement of many marine invertebrate larvae is biofilm (Hadfield 2011). Biofilms are defined as 'matrix-enclosed bacterial populations adherent to each other and/or to surface or interfaces' (Costerton et al. 1995). Dissolved organic molecules form thin layers on newly submerged surfaces, followed by the attachment of bacteria as the primary colonizers, and a variety of eukaryotic organisms as secondary colonizers (Zobel \& Allen 1935). The structure of biofilm continues to be highly heterogeneous as extracellular polymeric substances (EPS) are secreted, offering bacteria and other microorganisms protection and resistance to environmental stress (Wolfaardt et al. 1999). Biofilms provide a stable structure for bacteria to aggregate and function as a community (Costerton et al. 1995). Previous studies have shown that biofilms provide settlement cues for a diverse range of invertebrate taxa (Hadfield 2000). Biofilms also function to facilitate adhesion of larvae in the pro- 
cess of settling and of juveniles as they continue to develop on a substratum (Zardus et al. 2008).

This study examines the settlement of the larvae of Pocillopora damicornis (Linnaeus, 1758), which is an Indo-Pacific coral that is a significant component of the reef community in Hawaii. The life cycle of many anthozoans involves a planula stage - a dispersal phase in which the larva continues to swim in the water column and across substrata until it becomes metamorphically competent and encounters a suitable substratum on which to settle and metamorphose into a polyp (Müller \& Leitz 2002). The reproductive strategies of corals vary between broadcast spawning and brooding, and planktonic periods also vary greatly. Miller \& Mundy (2003) found that broadcast spawners may settle as soon as 2 to $3 \mathrm{~d}$ after fertilization. However, some broadcast spawners can remain in the plankton for up to $244 \mathrm{~d}$ when a suitable substratum is not encountered (Graham et al. 2008). The larvae of brooding corals also exhibit a wide range of planktonic periods, with some settling within $24 \mathrm{~h}$ after release (Carlon \& Olson 1993). $P$. damicornis is a brooder and its larvae can settle at any time between $2 \mathrm{~h}$ and up to $100 \mathrm{~d}$ after release (Harrigan 1972, Richmond 1987). Settlement refers to the descent of the planula from the water column and its attachment at the aboral end to a substratum. This is subsequently followed by metamorphosis, which is characterized by the flattening of the larva in the oral-aboral direction, secretion of a calcareous base, and development of tentacle buds to form the polyp (Vandermeulen 1974). Metamorphosis, in the broader context of most invertebrate larvae, is usually an irreversible process (Hadfield 2000). However, in the special case of $P$. damicornis, reversible metamorphosis has been observed under conditions of environmental stress or energy constraint (Richmond 1985).

Many cnidarian larvae require a natural cue that indicates an acceptable substratum, and inductive cues range broadly across species. Microbial cues that induce metamorphosis of cnidarian larvae have been well studied in hydrozoans (Müller 1973, Freeman \& Ridgway 1990, Seipp et al. 2007) and scyphozoans (Fleck \& Fitt 1999). Anthozoans, particularly corals, utilize a diverse range of cues. Cues can be associated with crustose coralline algae (CCA) (Morse et al. 1988, 1996, Baird et al. 2003, Baird \& Morse 2004, Harrington et al. 2004, Golbuu \& Richmond 2007, Kitamura et al. 2007, Ritson-Williams et al. 2010, Arnold et al. 2010, Price 2010) or marine bacteria and biofilms (Negri et al. 2001, Webster et al. 2004). Four species of Acropora (A. tenuis, A. millepora, A. palmata, and A. cervicornis) have been shown to preferentially settle on a particular species of CCA, Titanoderma prototypum (Harrington et al. 2004, Ritson-Williams et al. 2010), which is also preferred by other hard corals (Pocillopora spp. and Porites spp.) (Arnold et al. 2010, Price 2010). Another species of CCA, Hydrolithon boergesenii, is a preferred substratum for A. palmata and A. cervicornis (Ritson-Williams et al. 2010). Many studies testing the settlement of various coral species have led to the conclusion that CCA play a major role in settlement, with different coral species preferring a different species of CCA. Negri et al. (2001) found that although a sterilized CCA (Hydrolithon onkodes) could induce settlement in the 2 species of Acropora they studied (A. willisae and A. millepora), a particular bacterial strain isolated from this CCA also induced settlement in the absence of CCA. Thus, the authors concluded that CCA might not be the sole inducer of coral settlement in these species. Microbial biofilms alone, in the absence of CCA, also induced settlement in larvae of A. microphthalma (Webster et al. 2004). Golbuu \& Richmond (2007) examined 2 species of corals in Guam and found that one (Goniastrea retiformis) preferentially settled on CCA, while the other (Stylaraea punctata) settled on biofilmed carbonate rubble. Thus, settlement substrata vary greatly among coral species, and whether the inductive cue originates from CCA or bacteria is coral-species specific.

The larvae of Pocillopora damicornis in Hawaii have been shown not to be very selective and to settle on any biofilmed surface (Harrigan 1972). The same is true for P. damicornis in Australia (Harriott 1983). It has been shown that the biofilm bacterial communities can differ vastly among different CCA species (Johnson et al. 1991) as well as among non-biological surfaces at different depths and times (Webster et al. 2004). Therefore, different bacterial species may affect settlement of coral larvae differently. P. damicornis is a brooder that produces larvae year-round according to the lunar cycle (Richmond \& Jokiel 1984, Jokiel 1985). The planulae remain planktonic in the absence of a suitable substratum for settlement. However, they will settle within $24 \mathrm{~h}$ in the presence of a biofilmed surface. The goal of this study is to determine which species of bacteria would induce metamorphosis of $P$. damicornis. The specific questions to be addressed are:

(1) Is there specificity in the inductive capacities of different bacterial species?

(2) Are inductive capacities associated with bacterial phylogeny, in which strongly inductive species are taxonomically related?

(3) Are inductive bacterial species associated with the particular reef substratum from which they were isolated?

(4) Does bacterial density differentially affect larval settlement?

(5) Can different bacterial species inhibit or enhance each other's inductive capacities when combined in a mixed-species biofilm? 


\section{MATERIALS AND METHODS}

Collection of larvae. Colonies of Pocillopora damicornis ( $10 \mathrm{~cm}$ diameter) were collected from Kaneohe Bay, Oahu and transported to sea tables (shallow seawater tanks) at the Kewalo Marine Laboratory (Honolulu, HI). Corals received running seawater and plentiful sunlight. Colonies were transferred into individual containers, and larvae that were produced overflowed into $200 \mu \mathrm{m}$ sieved containers in which the larvae were retained as described by Richmond \& Jokiel (1984). Larvae released from several adult colonies were combined to increase variability in the populations used in settlement assays. They were maintained at $25^{\circ} \mathrm{C}$ in glass finger bowls with daily changes of filtered seawater (FSW) as described by Harrigan (1972).

Isolation of bacteria. Bacteria were isolated from 3 replicates of several different biological and nonbiological surfaces on a reef adjacent to the Hawaii Institute of Marine Biology (Kaneohe, HI). Non-biological surfaces included glass slides placed on the reef flat for 1 to 2 mo to develop a biofilm. Biological surfaces included the corals Porites compressa, Pocillopora damicornis, Montipora capitata, crustose coralline algae (CCA), and the alga Gracilaria salicornia. Biofilms were scraped off of the glass slides with a sterile razor blade as a concentrated sample in $1 \mathrm{ml}$ of sterile FSW. A small branch of each coral and algal sample was placed in individual microcentrifuge tubes with $1 \mathrm{ml}$ of sterile FSW and vortexed for 4 rounds of $5 \mathrm{~min}$ each to remove biofilms off the surfaces. Tubes were placed on ice for 1 min between rounds. Each sample was serially diluted to $10 \%, 1 \%$, and $0.1 \%$ of the original concentration. Following dilution, $100 \mu \mathrm{l}$ of each diluted sample was spread onto an agar plate consisting of halfstrength seawater-tryptone $(1 / 2 \mathrm{SWT})$ (Boettcher \& Ruby 1990) for bacterial colonies to develop. The different colonies that developed on the agar were separated based on morphological characteristics and streaked onto a new plate for further isolation. Once isolates were purified, the colonies were grown in liquid $1 \frac{1}{2}$ SWT and stored as stocks containing $80 \%$ glycerol at $-80^{\circ} \mathrm{C}$.

Settlement assays. To assess the competence of larvae and the inductive strength of bacteria, settlement experiments were conducted in $35 \times 10 \mathrm{~mm}$ polystyrene Petri dishes containing (1) sterilized FSW alone (as a negative control); (2) a natural complex biofilm grown for $5 \mathrm{wk}$ in a sea table and consisting of multiple species of bacteria (as a positive control); and (3) biofilms consisting of single species isolated from the field (as experimental treatments). Fifty-two bacterial isolates were tested.

To prepare bacteria for these tests, a small sample of each bacterial isolate was grown in $40 \mathrm{ml}$ of liquid $1 / 2$ SWT overnight at room temperature, with shaking.
The optical density (OD) for each sample was read at $600 \mathrm{~nm}$ to determine bacterial cell density. Concentrations were adjusted by removing the liquid $1 / 2 \mathrm{SWT}$ from these bacterial cultures via centrifugation and replacing it with the appropriate volume of sterile FSW to obtain desired inoculation densities. The bacteriain-FSW mixtures were inoculated into Petri dishes and left to stand for $1 \mathrm{~h}$ for bacteria to attach to the bottom of the dish and develop a monospecific biofilm. Five replicates (dishes) with 10 larvae each were set up per treatment. Competent larvae ( $>7 \mathrm{~d}$ old) were introduced into these treatments at room temperature $\left(25^{\circ} \mathrm{C}\right)$ and left for $24 \mathrm{~h}$, followed by the quantification of larvae that had completed metamorphosis.

Identification by $16 \mathrm{~S}$ rRNA gene sequence analysis. The bacterial isolates were grown overnight in liquid $1 / 2 \mathrm{SWT}$ and incubated at room temperature $\left(25^{\circ} \mathrm{C}\right)$. Genomic DNA was extracted using an Ultra Clean microbial DNA isolation kit according to the established protocol (MoBio Laboratories). The sequence coding for the 16S rRNA gene was amplified using $\mathrm{PCR}$, with the following forward and reverse bacterial specific oligonucleotide primers: 8-27F (5'-AGA GTT TGA TCC TGG CTC AG-3') and 1492R (5'-GGT TAC CTT GTT ACG ACT T-3') (Weisburg et al. 1991). The reaction conditions included an initial denaturation at $94^{\circ} \mathrm{C}$ for $5 \mathrm{~min}$, an annealing temperature of $50^{\circ} \mathrm{C}$ for $90 \mathrm{~s}$, followed by an amplification phase of 35 cycles at $72^{\circ} \mathrm{C}$ for $2 \mathrm{~min}$ each, and ending at $72^{\circ} \mathrm{C}$ for $10 \mathrm{~min}$. PCR products were cleaned with 1:1 exonuclease I:sunup alkaline phosphatase (SAP) and sent immediately to the Advanced Studies in Genomics, Proteomics and Bioinformatics sequencing facility at the University of Hawaii at Manoa (Honolulu, HI). Nearest relatives were obtained by BLAST searches in the GenBank database on the National Center for Biotechnology Information (NCBI) website. Bacterial species were identified by their closest match with a criterion of $>94 \%$ similarity.

Sequence alignment and phylogenetic analyses. Sequences obtained from isolates and their nearest relatives were aligned using the built-in ClustalW program in MEGA 4.0 (Tamura et al. 2007). All positions were included and gaps were treated as missing characters. Neighbor-joining (NJ) methods using the minimum evolution (ME) criteria were used to estimate pairwise distances in MEGA 4.0. These results were compared with parsimony and maximum likelihood (ML) analyses conducted in PAUP 4.01b.10 (Swofford 2002) and Bayesian analysis in MrBayes 3.0b4 (Hulsenbeck \& Ronquist 2001) using Markov Chain Monte Carlo (MCMC) methods (Geyer 1991). The outgroup taxon selected for tree construction was Escherichia coli MPEC Y-69 (Accession no. AB045731). Trees were constructed using either MEGA 4.0 or PAUP 4.01b.10. 
Variation in densities of monospecific biofilms. Based on the settlement assays conducted with the 52 bacterial isolates, 4 different species of various inductive capacities (Pseudoalteromonas luteoviolacea, Alteromonas alvinellae, Vibrio harveyi, and Bacillus firmus) were further tested by varying their biofilm densities. Bacterial growth curves for each species were established by quantitatively counting cells using OD $600 \mathrm{~nm}$ values. Cell densities were adjusted to $10^{6}$ to $10^{9}$ cells ml $\mathrm{m}^{-1}$ and inoculated into $35 \times 10 \mathrm{~mm}$ Petri dishes as described above for settlement assays. Controls included sterilized FSW alone (as a negative control) and a natural biofilm consisting of multiple species of bacteria (as a positive control). Five replicates with 10 larvae per dish were set up for each cell density of each bacterial species to determine the percentage of larvae that would complete metamorphosis. Another 5 replicates per cell density of each bacterial species were set up in the same way but without the addition of larvae, and then fixed in $3.7 \%$ formaldehyde in FSW, followed by washes with phosphatebuffered saline (PBS). These dishes were stained with propidium iodide $\left(2 \mu \mathrm{g} \mathrm{ml}^{-1}\right.$; Molecular Probes) to visualize bacterial cell nuclei and to quantify the number of cells per $\mathrm{mm}^{2}$ present in each monospecific biofilm. Five fields of view (area: $0.0196 \mathrm{~mm}^{2}$ ) for each dish were imaged using a confocal microscope (Zeiss LSM510).

Biofilms consisting of two species of bacteria. To determine whether inductive capacity differed between mono- and multi-species biofilms, biofilms that included 2 species of bacteria were made. Pseudoalteromonas luteoviolacea was paired with each of 3 other species (Alteromonas alvinellae, Vibrio harveyi, or Bacillus firmus) and inoculated to obtain a final density that was equivalent to the density of 1 species alone. Monospecific biofilms (as described in 'Settlement assays') were made by inoculating Petri dishes at cell densities of $10^{8}$ cells $\mathrm{ml}^{-1}$. In a biofilm composed of 2 bacterial species, each species was inoculated at a cell density of $0.5 \times 10^{8}$ cells $\mathrm{ml}^{-1}$. Controls included sterilized FSW alone (as a negative control), a natural biofilm consisting of multiple species of bacteria (as a positive control), and biofilms consisting of the single species tested (for comparison). Five replicates with 10 larvae per dish were set up for each treatment. The percentage of larvae that completed metamorphosis was determined after $24 \mathrm{~h}$. Another 5 replicates per treatment were set up in the same way but without the addition of larvae, and then fixed, stained, and imaged as described in 'Variation in densities of monospecific biofilms'. The 2 bacterial species in one dish could not be distinguished from each other by size or shape under the microscope; therefore, the total numbers of cells per $\mathrm{mm}^{2}$ present for both species were counted together.
Statistical analyses. Results from the various settlement experiments were graphed and analyzed using SigmaPlot 11.0 (Systat Software). Percentages of metamorphosis were arcsine transformed and then analyzed using 1-way ANOVA for all experiments, except for the comparison of biofilm densities of mixedspecies biofilms, in which a Kruskal-Wallis ANOVA was used. All pairwise multiple comparisons were done using a Tukey test.

\section{RESULTS}

\section{Inductive capacities and source of isolates}

The percentage of larvae of Pocillopora damicornis that metamorphosed in response to monospecific bacterial films varied among bacterial species (Fig. 1). The negative control (FSW) yielded 0\% metamorphosis, whereas the positive control (natural biofilm) induced $70 \%$ metamorphosis. Relative to these controls, 3 bacterial species identified as G23a, B1P, and M23b were considered strongly inductive with percentages of metamorphosis (60 to $72 \%$ ) that were comparable to that of natural biofilm. The remaining species were either moderately (10 to $32 \%$ metamorphosis), weakly ( 2 to $8 \%$ ), or non-inductive $(0 \%)$. A complete list of the 52 different isolates tested in settlement experiments is shown in Table 1. These isolates included species from the genera Pseudoalteromonas, Alteromonas, Bacillus, Brevibacillus, Cytophaga, Ruegeria, Vibrio, and Thalassomonas. 16S rRNA gene sequence analysis identified some isolates as the same species. The strongly inductive species were identified as such: G23a as a Pseudoalteromonadaceae bacterium, B1P as Pseudoalteromonas luteoviolacea, and M23b as Thalassomonas agarivorans. Therefore, inductive species are not limited to a single genus. Furthermore, not all species in a given genus are inductive, as both Pseudoalteromonas and Thalassomonas included species with a range of inductive capacities. Each of the 3 strongly inductive species was obtained from a different surface: The Pseudoalteromonadaceae bacterium from the surface of the alga Gracilaria salicornia; Pseudoalteromonas luteoviolacea from a biofilmed glass slide; and Thalassomonas agarivorans from the surface of the coral Montipora capitata. Therefore, the inductive capacity of bacteria is not associated with the type of surface from which they were isolated.

\section{Inductive capacities and phylogenetic relationships}

Phylogenetic analyses using the various methods and models produced similar results. A neighborjoining tree using minimum evolution criteria was 
Fig. 1. Pocillopora damicornis. Induction of metamorphosis (mean percentage of larvae that metamorphosed $+\mathrm{SE}$ ) by monospecific biofilms after $24 \mathrm{~h}$. Treatments include bacterial isolates (see Table 1 for species identification), sterilized filtered seawater (FSW negative control), and natural biofilm (NB; positive control). Relative to the metamorphosis (\%) seen in controls, isolates were assigned inductive capacities (see Table 1) labeled 'strong,' 'moderate,' 'weak,' or 'none.' $\mathrm{n}=5$ replicates per treatment (10 larvae per replicate)

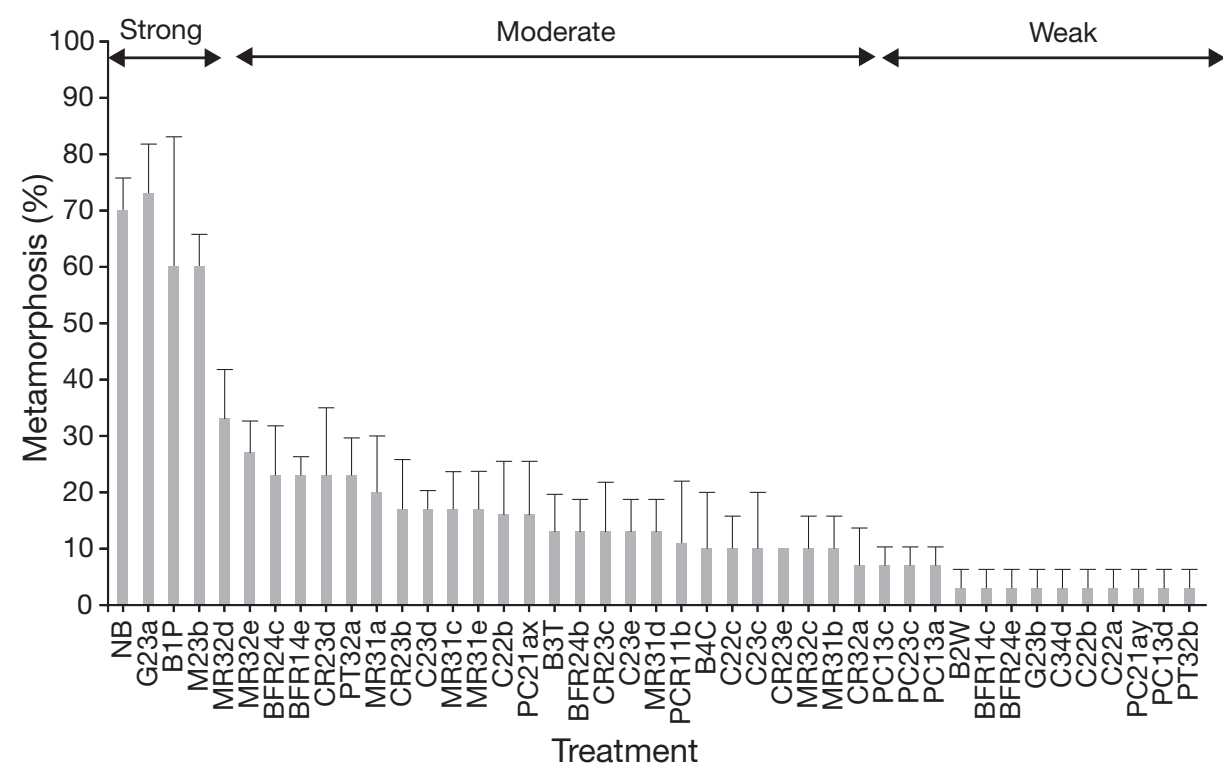

generated from the 52 isolates tested in settlement experiments, along with their closest relatives obtained from Genbank (Fig. 2). When sequences from Pseudoalteromonas and Thalassomonas species were aligned and analyzed using the same method, pairwise distances revealed significant differences when comparing 2 strongly inductive species to each other, versus 1 strongly inductive and 1 non-inductive species (Fig. 3). There is a $10.6 \%$ genetic distance between Pseudoalteromonas luteoviolacea and Thalassomonas agarivorans, which are 2 strongly inductive species belonging to different genera. However, there is only a $2 \%$ genetic distance between $P$. luteoviolacea and $P$. rubra, which are related species but with the latter being non-inductive. Therefore, closely related species do not necessarily have the same inductive capacity, and inductive capacity may not be inferred from the taxonomy of the species. The characterbased methods of analysis produced similar results (not shown). Parsimony and Bayesian analyses indicated the 2 strongly inductive species within the Pseudoalteromonas genus (G23a and B1P) and their closest BLAST matches to be monophyletic. All 3 methods showed $T$. agarivorans, the other strongly inductive species, to be a sister taxon to Thalassomonas loyana, which is a weakly inductive species. None of the trees, which included both distance- and charac-

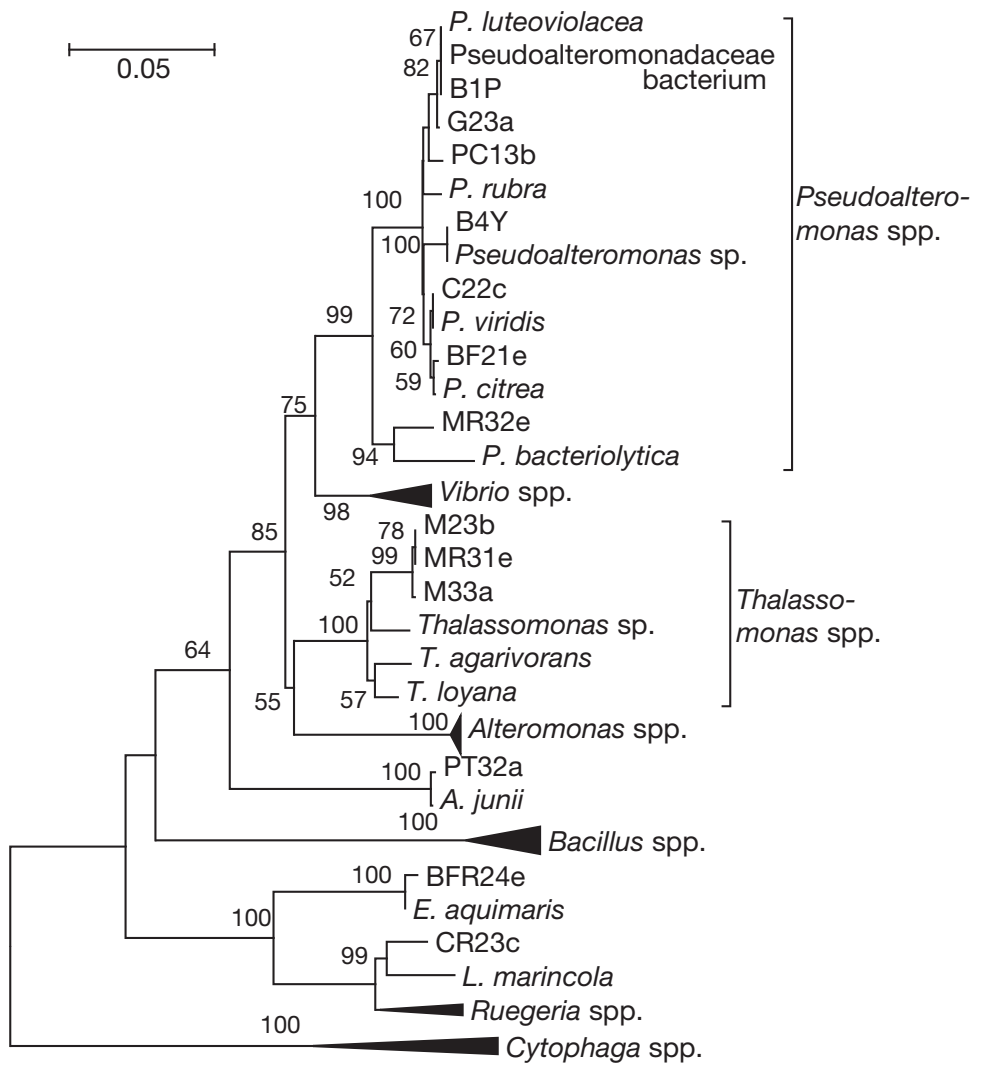

Fig. 2. Minimum evolution phylogenetic tree (Jukes-Cantor model) generated from analysis of 1345 nucleotides of 16S rRNA gene sequences from all bacterial isolates tested. Numbers on nodes: percentages indicating levels of bootstrap support, based on analysis of 1000 re-sampled data sets; only values $>50 \%$ are shown. Scale bar: 0.05 substitutions per nucleotide position; filled triangles: collapsed clades 
Table 1. 16S rRNA gene sequence analysis of 52 bacterial isolates. Source: type of reef surface where the isolate was obtained. Closest relatives were retrieved from a Basic Local Alignment Search Tool (BLAST) search in GenBank. Inductive capacity (strong, moderate, weak, and none) is based on experimental results shown in Fig. 1. CCA: crustose coralline algae

\begin{tabular}{|c|c|c|c|c|c|}
\hline Isolate & $\begin{array}{c}\text { Accession } \\
\text { no. }\end{array}$ & Source & BLAST closest match & $\begin{array}{l}\text { Accession no. of } \\
\text { closest match }\end{array}$ & $\%$ similarity \\
\hline \multicolumn{6}{|l|}{ Strong } \\
\hline $\mathrm{B} 1 \mathrm{P}$ & HQ439502 & Slide & Pseudoalteromonas luteoviolacea & DQ504310 & 99 \\
\hline G23a & HQ439503 & Gracilaria & Pseudoalteromonadaceae bacterium & DQ005867 & 99 \\
\hline $\mathrm{M} 23 \mathrm{~b}$ & HQ439504 & Montipora & Thalassomonas agarivorans & DQ212914 & 96 \\
\hline \multicolumn{6}{|c|}{ Moderate } \\
\hline PT32a & HQ439505 & Porites & Acinetobacter junii & AY881242 & 96 \\
\hline B3T & HQ439506 & Slide & Alteromonas alvinellae & AF288360 & 99 \\
\hline MR32c & HQ439507 & Montipora & Alteromonas marina & AY881234 & 98 \\
\hline MR31d & HQ439508 & Montipora & Alteromonas sp. & AB262377 & 98 \\
\hline MR32d & HQ439509 & Montipora & Alteromonas sp. & AY626838 & 99 \\
\hline PC21ax & HQ439510 & Pocillopora & Alteromonas sp. & AB262377 & 97 \\
\hline BFR14e & HQ439511 & Slide & Bacillus licheniformis & EU113217 & 99 \\
\hline CR23d & HQ439512 & $\mathrm{CCA}$ & Bacillus sp. & DQ985053 & 99 \\
\hline CR23b & HQ439513 & CCA & Brevibacillus sp. & AY372923 & 99 \\
\hline MR31a & HQ439514 & Montipora & Brevibacillus sp. & AY372923 & 99 \\
\hline $\mathrm{C} 23 \mathrm{e}$ & HQ439515 & CCA & Cytophaga sp. & AB073567 & 94 \\
\hline $\mathrm{C} 23 \mathrm{~d}$ & HQ439516 & CCA & Cytophaga sp. & AB073567 & 99 \\
\hline CR23e & HQ439517 & $\mathrm{CCA}$ & Cytophaga sp. & AB073590 & 95 \\
\hline CR23C & HQ439518 & CCA & Loktanella marincola & EF202613 & 94 \\
\hline MR32e & HQ439519 & Montipora & Pseudoalteromonas bacteriolytica & AF173962 & 95 \\
\hline $\mathrm{C} 22 \mathrm{C}$ & HQ439520 & CCA & Pseudoalteromonas viridis & AB231329 & 99 \\
\hline PCR11b & HQ439521 & Pocillopora & Pseudoalteromonas viridis & AB231329 & 99 \\
\hline MR31b & HQ439522 & Montipora & Ruegeria sp. & AJ391197 & 98 \\
\hline MR31c & HQ439523 & Montipora & Ruegeria sp. & AJ391197 & 98 \\
\hline BFR24c & HQ439524 & Slide & Ruegeria sp. & AY576770 & 94 \\
\hline $\mathrm{BFR} 24 \mathrm{~b}$ & HQ439525 & Slide & Ruegeria sp. & AY576770 & 97 \\
\hline MR31e & HQ439526 & Montipora & Thalassomonas sp. & AB304803 & 96 \\
\hline $\mathrm{C} 22 \mathrm{~b}$ & HQ439527 & CCA & Vibrio fortis & AJ514915 & 97 \\
\hline $\mathrm{B} 4 \mathrm{C}$ & HQ439528 & Slide & Vibrio harveyi & AY911396 & 99 \\
\hline $\mathrm{C} 23 \mathrm{c}$ & HQ439529 & $\mathrm{CCA}$ & Vibrio sp. & EU082035 & 97 \\
\hline \multicolumn{6}{|l|}{ Weak } \\
\hline PC21ay & HQ439530 & Pocillopora & Alteromonas littorea & AY428573 & 97 \\
\hline $\mathrm{PC} 23 \mathrm{C}$ & HQ439531 & Pocillopora & Alteromonas sp. & AB015135 & 98 \\
\hline PC13a & HQ439532 & Pocillopora & Alteromonas sp. & AB015135 & 98 \\
\hline C34d & HQ439533 & $\mathrm{CCA}$ & Alteromonas sp. & AB262378 & 98 \\
\hline BFR14c & HQ439534 & Slide & Bacillus firmus & AB271750 & 97 \\
\hline G23b & HQ439535 & Gracilaria & Bacillus firmus & AB271750 & 97 \\
\hline CR32a & HQ439536 & CCA & Coccinimonas marina & EF108213 & 95 \\
\hline PT32b & HQ439537 & Porites & Colwellia sp. & EF635235 & 94 \\
\hline BFR24e & HQ439538 & Slide & Erythrobacter aquimaris & AY461443 & 98 \\
\hline B2W & HQ439539 & Slide & Photobacterium eurosenbergii & AJ842346 & 98 \\
\hline $\mathrm{PC} 13 \mathrm{c}$ & HQ439540 & Pocillopora & Pseudoalteromonas rubra & DQ005900 & 99 \\
\hline PC13d & HQ439541 & Pocillopora & Pseudoalteromonas rubra & DQ005900 & 99 \\
\hline \multicolumn{6}{|l|}{ None } \\
\hline MR32a & HQ439542 & Montipora & Alteromonas sp. & AB015135 & 98 \\
\hline M32c & HQ439543 & Montipora & Alteromonas sp. & AB015135 & 97 \\
\hline PCR11a & HQ439544 & Pocillopora & Alteromonas sp. & AB015135 & 98 \\
\hline PT24a & HQ439545 & Porites & Alteromonas sp. & DQ412077 & 98 \\
\hline $\mathrm{BF} 21 \mathrm{e}$ & HQ439546 & Slide & Pseudoalteromonas citrea & DQ401135 & 99 \\
\hline G31a & HQ439547 & Gracilaria & Pseudoalteromonas rubra & DQ005900 & 99 \\
\hline PC13b & HQ439548 & Pocillopora & Pseudoalteromonas rubra & DQ005900 & 99 \\
\hline B1M & HQ439549 & Slide & Pseudoalteromonas rubra & DQ005900 & 99 \\
\hline $\mathrm{PC} 22 \mathrm{a}$ & HQ439550 & Pocillopora & Pseudoalteromonas sp. & AY028197 & 96 \\
\hline B4Y & HQ439551 & Slide & Pseudoalteromonas sp. & AJ874351 & 99 \\
\hline РT32c & HQ439552 & Porites & Staphylococcus equorum & AB334773 & 99 \\
\hline M33a & HQ439553 & Montipora & Thalassomonas loyana & AY643537 & 96 \\
\hline
\end{tabular}




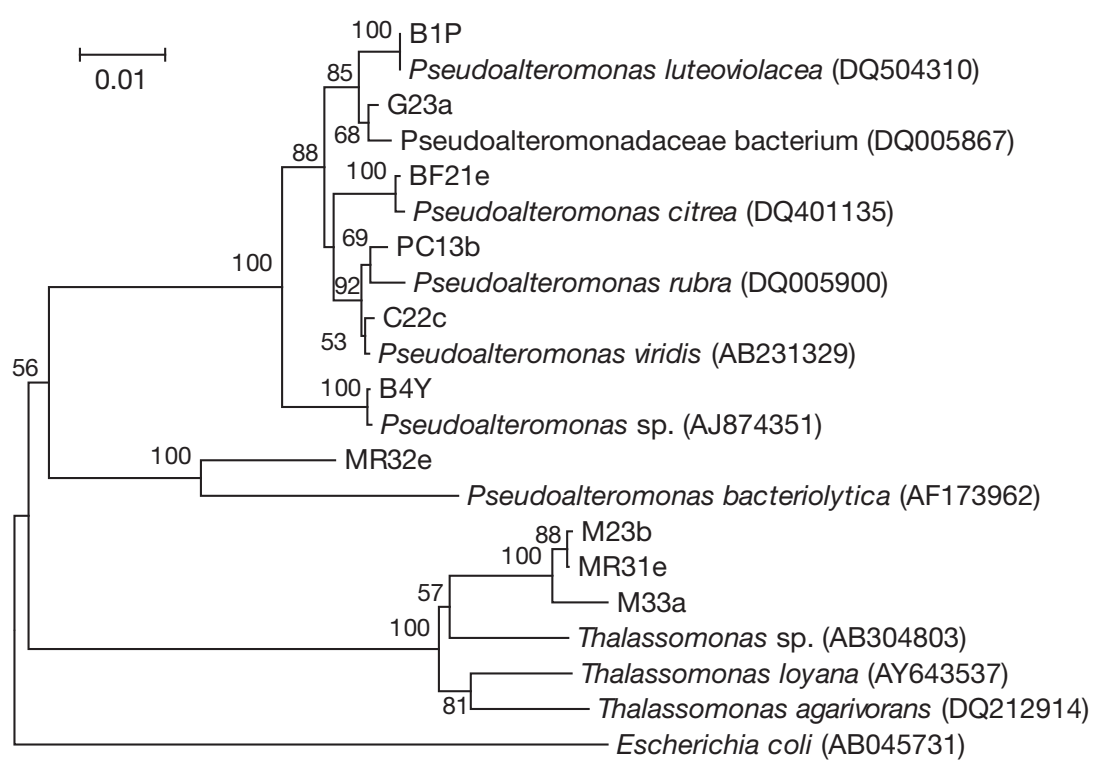

Fig. 3. Minimum evolution phylogenetic tree (Jukes-Cantor model) generated from analysis of $1345 \mathrm{nt}$ of 16S rRNA gene sequences from selected bacterial isolates. Numbers on nodes: percentages indicating levels of bootstrap support, based on analysis of 1000 re-sampled data sets; only values $>50 \%$ are shown. Scale bar: 0.01 substitutions per nucleotide position

ter-based methods, appears to indicate a relationship between inductive capacity and phylogeny.

\section{Variation in densities of monospecific biofilms}

Variation in cell densities for some bacterial species affected larval settlement (Fig. 4). The cell densities at which bacteria were inoculated into dishes positively correlated with the densities they would form in biofilms. As expected, an increase in inoculation density resulted in an increase in biofilm density for all 4 species of bacteria (Pseudoalteromonas luteoviolacea, Alteromonas alvinellae, Vibrio harveyi, and Bacillus firmus) examined (Fig. 5). Although all 4 bacterial species were inoculated at the same densities, the biofilm densities they formed varied, as A. alvinellae, V. harveyi, and $B$. firmus made much denser biofilms than $P$. luteoviolacea. The inductive capacity of a bacterial species for larval metamorphosis may depend on the density of the biofilm it forms, but only for certain species. The different densities at which $A$. alvinellae, $V$. harveyi, and $B$. firmus were inoculated into dishes resulted in no significant differences in the percentage of larvae that metamorphosed (Fig. 4 ; A. alvinellae: $\mathrm{p}=$ 0.096, $\mathrm{n}=5 ;$ V. harveyi: $\mathrm{p}=0.796, \mathrm{n}=5 ;$ B. firmus: $\mathrm{p}=$ $1.000, \mathrm{n}=5$ ). Varying the inoculation density for $P$. luteoviolacea, however, significantly affected planular metamorphosis (Fig. 4; $\mathrm{p}=0.002, \mathrm{n}=5$ ). Metamorpho- sis of planulae ranged from 14 to $68 \%$ at bacterial cell densities between $10^{6}$ and $10^{8}$ cells $\mathrm{ml}^{-1}$; moreover, all larvae were either sick or dead when the inoculation density was $10^{9}$ cells $\mathrm{ml}^{-1}$. These metamorphosis results were also reflected in the biofilm densities that each of the bacterial species had formed (Fig. 6). Therefore, varying the biofilm density affected metamorphosis only when the bacterial species was strongly inductive (P. luteoviolacea). Biofilm density had no effect on metamorphosis when the bacterial species were moderately (A. alvinellae and $V$. harveyi) or weakly (B. firmus) inductive. Despite the lower density of the biofilm produced by $P$. luteoviolacea relative to the biofilms formed by A. alvinellae, $V$. harveyi, and $B$. firmus, $P$. luteoviolacea remained a strong inducer. Thus, strongly inductive species became moderately inductive when their biofilm density was reduced, but moderately and weakly inductive species did not become strongly inductive when their biofilm densities were increased.

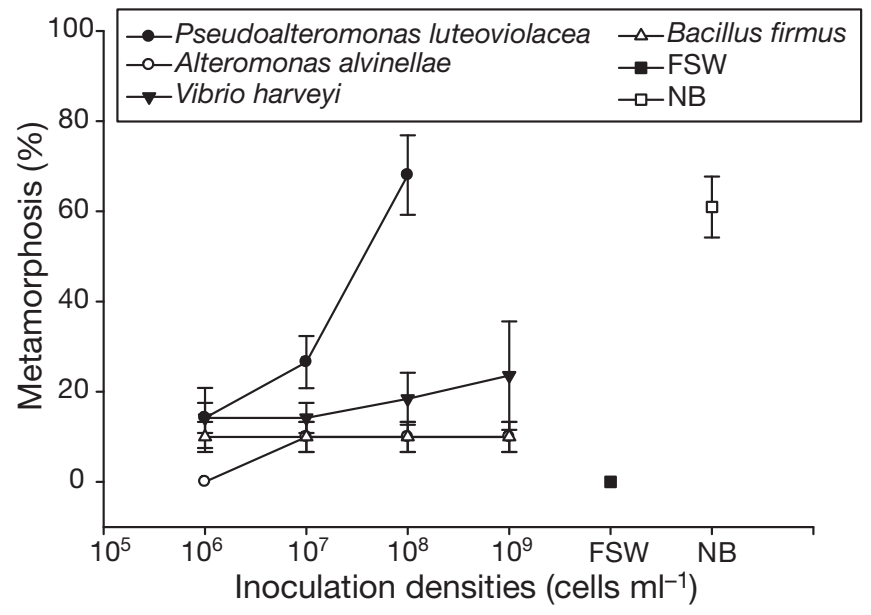

Fig. 4. Pocillopora damicornis. Metamorphosis (mean percentage of larvae that metamorphosed $\pm \mathrm{SE}$ ) in response to different bacterial inoculation densities after $24 \mathrm{~h}$. Four bacterial species of different inductive capacities were tested at different densities: a strongly inductive species (Pseudoalteromonas luteoviolacea), 2 moderately inductive species (Alteromonas alvinellae and Vibrio harveyi), and a weakly inductive species (Bacillus firmus). FSW: sterilized filtered seawater, negative control; NB: natural biofilm, positive control. $\mathrm{n}=5$ replicates per treatment (10 larvae per replicate) 


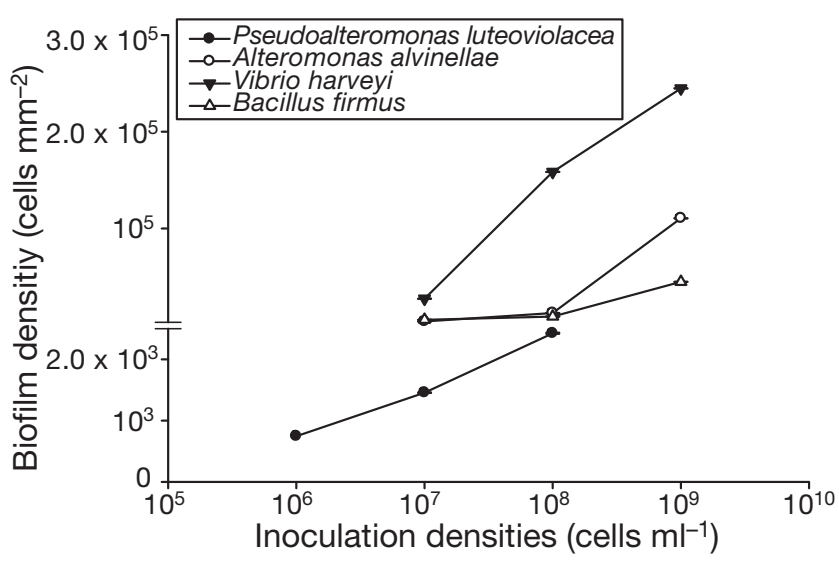

Fig. 5. Biofilm densities (mean \pm SE) developed from different bacterial inoculation densities for Pseudoalteromonas luteoviolacea, Alteromonas alvinellae, Vibrio harveyi, and Bacillus firmus. Biofilm densities were determined by counting bacterial cells in an area $\left(0.0196 \mathrm{~mm}^{2}\right)$ of each biofilm. $\mathrm{n}=5 \mathrm{rep}$ licates (5 areas per replicate). Error bars are too small for the scale to be visible

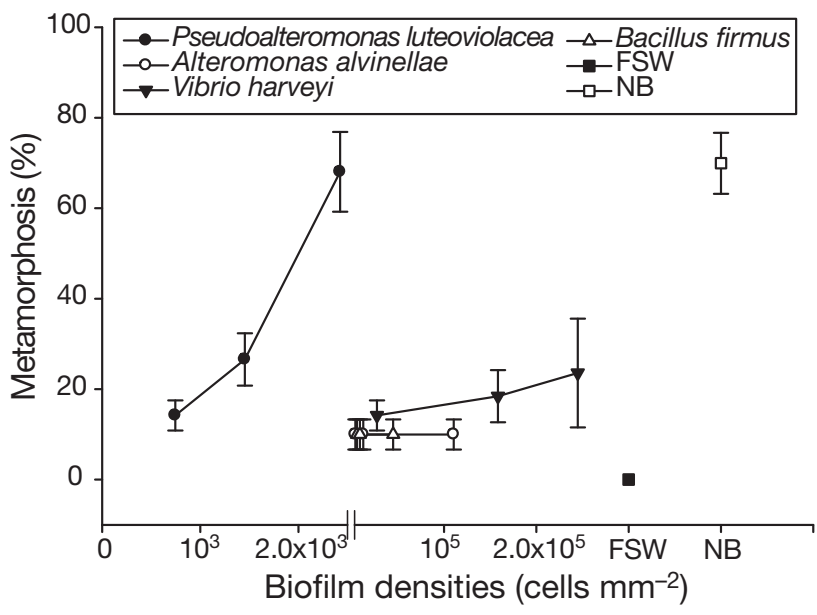

Fig. 6. Pocillopora damicornis. Metamorphosis (mean percentage of larvae that metamorphosed $\pm \mathrm{SE}$ ) in response to different biofilm densities after $24 \mathrm{~h}$ for Pseudoalteromonas luteoviolacea, Alteromonas alvinellae, Vibrio harveyi, and Bacillus firmus. FSW: sterilized filtered seawater, negative control; NB: natural biofilm, positive control. $\mathrm{n}=5$ replicates per treatment (10 larvae per replicate)

\section{Biofilms consisting of 2 species of bacteria}

When the strongly inductive species Pseudoalteromonas luteoviolacea was mixed with each of the 3 moderately or weakly inductive species to form a biofilm consisting of 2 bacterial species, the percentage of larvae that metamorphosed was significantly reduced (Fig. 7; $\mathrm{p}<0.001, \mathrm{n}=5$ ). Natural biofilm (used as a positive control) and $P$. luteoviolacea alone both yielded $\sim 60 \%$ metamorphosis, whereas Alteromonas alvinellae, Vibrio harveyi, and Bacillus firmus yielded

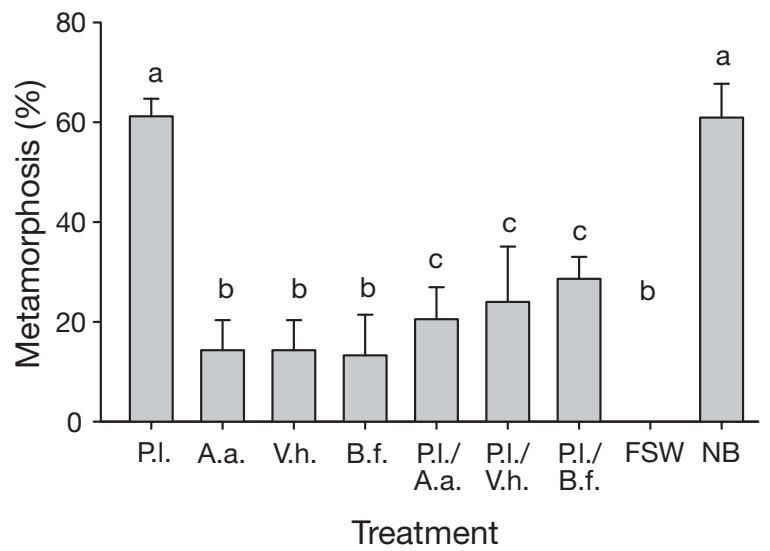

Fig. 7. Pocillopora damicornis. Metamorphosis (mean \% of larvae that metamorphosed $+\mathrm{SE}$ ) in response to mixed biofilms consisting of 2 bacterial species after $24 \mathrm{~h}$. Treatments included individual bacterial species (Pseudoalteromonas luteoviolacea, P.l.; Alteromonas alvinellae, A.a; Vibrio harveyi, V.h.; and Bacillus firmus, B.f.) and mixed biofilms in which $P$. luteoviolacea was combined with each of the remaining 3 species. FSW: sterilized filtered seawater, negative control; NB: natural biofilm, positive control. $\mathrm{n}=5$ replicates per treatment (10 larvae per replicate). Means with different letters are significantly different (1-way ANOVA; Tukey test, $\mathrm{p}<0.001, \mathrm{n}=5$ )

only $14 \%$ metamorphosis. When $P$. luteoviolacea was combined with $A$. alvinellae, $V$. harveyi, and $B$. firmus, metamorphosis was reduced to 20,24 , and $28 \%$, respectively. Unfortunately, biofilm densities for the individual bacterial species in a combination could not be determined because their cell types could not be distinguished when imaged. Moreover, the total biofilm densities in the mixed-species biofilms were not consistent or predictable (Fig. 8). Some interaction must occur between the 2 species in these biofilms; the total density of cells in a biofilm of $P$. luteoviolacea and $V$. harveyi was much less than that in a biofilm of $V$. harveyi alone, although the latter was significantly greater than that in a biofilm of $P$. luteoviolacea alone (Fig. 8; $\mathrm{p}<0.001, \mathrm{n}=5$ ).

\section{DISCUSSION}

The cue required for the settlement of many species of coral larvae originates from CCA (Morse et al. 1988, 1996, Golbuu \& Richmond 2007, Kitamura et al. 2007, Arnold et al. 2010, Price 2010, Ritson-Williams et al. 2010). Morse et al. (1996) found the cue from CCA to be a cell-wall bound polysaccharide with a high molecular weight. Calcareous substrata, such as coral skeleton or rubble without CCA may also induce settlement (Heyward \& Negri 1999). In addition to the CCA-generated morphogens, bacteria associated with 


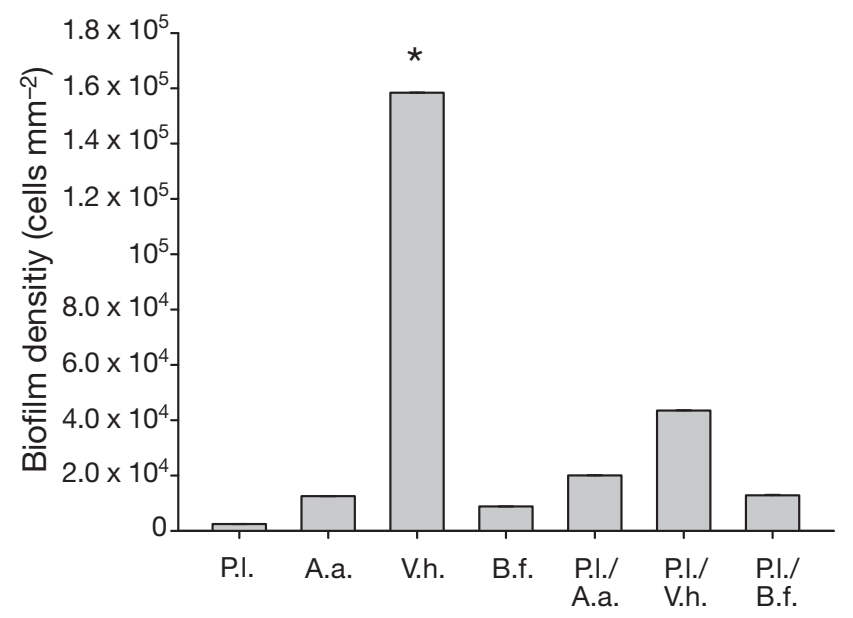

Treatment

Fig. 8. Biofilm densities (mean \pm SE) developed from individual bacterial species (Pseudoalteromonas luteoviolacea, P.l.; Alteromonas alvinellae, A.a; Vibrio harveyi, V.h.; and Bacillus firmus, B.f.) and mixed-species biofilms in which $P$. luteoviolacea was combined with each of the remaining 3 species. Biofilm densities were determined by counting bacterial cells in an area $\left(0.0192 \mathrm{~mm}^{2}\right)$ of each biofilm. Because bacterial species in a mixed-species biofilm could not be differentiated for the counting of the number of cells represented by each species, only total biofilm densities are depicted for these combinations. $\mathrm{n}=5$ replicates ( 5 areas per replicate); error bars are too small for the scale to be visible. ${ }^{*} p<0.001$ for the comparison between $V$. harveyi and all other treatments using Kruskal-Wallis ANOVA and Tukey test)

CCA have been found to produce cues for the settlement of some coral species, specifically 2 species of Acropora, for which bacteria were inductive both in biofilms and in suspension (Negri et al. 2001). Golbuu \& Richmond (2007) who studied settlement stimuli for corals in Guam found one coral species (Goniastrea retiformis) that preferred CCA and another (Stylaraea punctata) that preferred biofilm. Thus, settlement preferences differ among species of corals. In our experiments, we first noted that the larvae of Pocillopora damicornis would settle on biofilmed slides as well as on $\mathrm{CCA}$, leading us to investigate the inductive capacity of bacteria in greater depth. Our study revealed that bacteria in surface biofilms provide the primary cue.

Determining the characteristics of a biofilm and the type of bacterial community that grows on different substrata depends on many factors including location, age, and the physical and chemical nature of the surface (Barott et al. 2011). Larvae of the coral Acropora microphthalma preferred to settle on older biofilms (developed on glass slides placed in the reef for $8 \mathrm{wk}$ ), and on biofilms grown in shallow versus deep water of a reef (Webster et al. 2004). These settlement differ- ences were a result of differences in the bacterial communities, as verified by techniques such as fluorescence in situ hybridization (FISH) and denaturing gradient gel electrophoresis (DGGE) (Webster et al. 2004). Temporal variation in the bacterial community in a harbor also affected larval settlement of the polychaete tubeworm Hydroides elegans (Shikuma \& Hadfield 2006). The physical and chemical nature of a surface also affects the type of bacterial community that grows on it. Typically, different bacterial species are found in biofilms and in the nearby planktonic community (Costerton et al. 1995, Pasmore \& Costerton 2003). For example, the bacterial community in the water column greatly differs from that associated with the surfaces of corals (Johnston \& Rohwer 2007) and CCA (Johnson et al. 1991). In a harbor, the bacterial community may also differ between biofilms on surfaces and the water column; moreover, 2 bacterial species (particularly Escherichia coli and Vibrio cholerae) were found to be highly dominant on abiotic surfaces in Hawaiian harbors (Shikuma \& Hadfield 2010).

Larval settlement of Pocillopora damicornis was highest on 5 wk biofilms (pers. obs.), suggesting that biofilm age has an effect. However, the surface from which bacteria were isolated did not matter. The 3 strongly inductive bacterial species (the Pseudoalteromonadaceae bacterium, Pseudoalteromonas luteoviolacea, and Thalassomonas agarivorans) were originally isolated from different surfaces. Furthermore, all 6 biological and non-biological surfaces (Porites compressa, Pocillopora damicornis, Montipora capitata, CCA, Gracilaria salicornia, and glass slides) from which bacteria were collected in the field yielded both inductive and non-inductive bacteria. However, the abundance of each bacterial species on these surfaces is unknown because techniques such as FISH were not employed to screen whole bacterial communities on each surface.

An attempt was made in the present study to determine whether bacterial species that were similar in inductive capacities are phylogenetically related, given that bacteria can be grouped by their different metabolic functions (Unabia \& Hadfield 1999) as well as DNA sequence similarities (Huang \& Hadfield 2003). The present study found no correlation between inductive capacities and phylogenetic relationships. With 3 different, strongly inductive bacterial species belonging to 2 genera, the results suggest that the inductive substance is not limited to a single phylum of bacteria. Therefore, new questions arise as to whether the inductive substance produced by bacteria is the same or different across different species of bacteria.

Previous studies have shown that specific bacterial species affect settlement in Hydroides elegans differently, and that a positive correlation exists between 
bacterial density and inductive capacity (Huang \& Hadfield 2003). In the present study, there was only a positive correlation when the density was increased for the strongly inductive bacterium Pseudoalteromonas luteoviolacea, but not for the 3 other tested species (Alteromonas alvinellae, Vibrio harveyi, and Bacillus firmus) that were moderately or weakly inductive. The inductive capacity of $P$. luteoviolacea was reduced as the biofilm density decreased. The density of any bacterial species that larvae actually encounter in the field is unknown. However, it has been shown in laboratory settings that although $P$. luteoviolacea makes lower density biofilms compared to other species, it remains strongly inductive, as explained by Hadfield (2011) and the present study.

Clearly, not all bacterial species from marine biofilms are equally inductive for the settlement of marine invertebrate larvae. Furthermore, this and other studies have demonstrated some connection between metamorphosis of marine invertebrate larvae and bacterial species of the genus Pseudoalteromonas (Hadfield 2011). Species belonging to this genus have been shown to induce settlement of the larvae of the hydrozoan Hydractinia echinata (Müller 1973, Seipp et al. 2007) and the corals Acropora willisae and A. millepora (Negri et al. 2001). The species Pseudoalteromonas luteoviolacea also induces metamorphosis in the larvae of the polychaete Hydroides elegans (Huang \& Hadfield 2003) and the sea urchin Heliocidaris erythrogramma (Huggett et al. 2006). Hence, the specificity of larval settlement in response to $P$. luteoviolacea may be due to unknown properties that are uniquely associated with this bacterial species, making it very inductive to a range of different invertebrate taxa. More research to test whether P. luteoviolacea could induce settlement of the larvae of other invertebrate taxa would further confirm these results. To date, there has been no concrete identification of the inductive substance(s), but narrowing the possibilities down to a specific species, such as $P$. luteoviolacea, may be the key to determining the actual chemical cue. The present study tested larval settlement on 8 different species of Pseudoalteromonas and found that $P$. luteoviolacea is indeed among the strongest inducers. An investigation into the genes in P. luteoviolacea that are involved in its inductive capacity would be a significant step (Hadfield 2011).

The formation of biofilms confers many physiological advantages for bacteria. While the planktonic stage allows for dissemination, embedding themselves in biofilm facilitates growth in a protected microenvironment (Costerton et al. 1995). Because bacteria are attracted to nutrients, biofilm formation enables bacteria to work cooperatively to concentrate dissolved organic matter (Hall-Stoodley et al. 2004). The attrac- tion of bacteria to each other provides the foundation for cell-cell signaling and communication (Stoodley et al. 2002, Pasmore \& Costerton 2003). These advantages are characteristic of both monospecific and complex biofilms, but the 2 types differ in surface structure. The general shapes found in monospecific films are mostly conical or mushroom-shaped, whereas complex films have greater variability in their structure (Costerton et al. 1995). Therefore, it is reasonable to ask how the functions of monospecific versus complex biofilms might differ and, in turn, how their inductive capacities might differ when bacterial species are alone or in multi-species combinations.

In the present study, when the strongly inductive species Pseudoalteromonas luteoviolacea was combined with moderately or weakly inductive species to make 2-species biofilms, the inductive capacities were reduced in comparison with that of the strongly inductive species alone. The decrease in metamorphosis may be attributed to 4 possible reasons: (1) interaction between the different bacterial species, in which the 3 less inductive species reduced the inductive capacity of $P$. luteoviolacea; (2) reduction of the density of $P$. luteoviolacea due to its inoculation in these combinations at half the density inoculated to dishes of $P$. luteoviolacea alone; (3) strong competition from the 3 less inductive species in biofilm formation (i.e. although inoculated at equal densities, biofilm densities might not be equal, with more cells of the other 3 species being present than cells of $P$. luteoviolacea); or (4) any combination of the above. The results might indeed be due to the second reason, a reduction in inoculation density of $P$. luteoviolacea, but it seems that the reduction in metamorphosis in all 3 combinations cannot be attributed to this reason alone. $P$. luteoviolacea, when combined with the other 3 species, was inoculated at $0.5 \times 10^{8}$ cells $\mathrm{ml}^{-1}$, which would correspond to a biofilm density of 1973 cells $\mathrm{mm}^{-2}$ (Fig. 5). This would be expected to yield $\sim 48 \%$ metamorphosis (Fig. 6). Metamorphosis on biofilms of all 3 combinations was only about half of this expected amount, suggesting that either the first or the third possibility might have also occurred, i.e. moderately and weakly inductive bacterial species reduced the inductive capacity of $P$. luteoviolacea, possibly by outcompeting it for space or nutrients. However, it is still unclear how this might have occurred as the cell types of the different bacterial species could not be distinguished in this study. Microorganisms within a biofilm could be distinguished using confocal microscopy, and cells of 2 different bacterial species that could be distinguished by cell type were previously observed to sort themselves into separate layers when they were combined in a biofilm (Hadfield 2011). This suggests that larvae that are exposed to a biofilm consisting of 2 
species may encounter only the bacterial species that is closer to the surface of the biofilm. Although the cell types could not be differentiated in our mixed-species biofilms when imaged, we suspect that a similar situation occurred in this study. The interaction between bacterial species remains complex, and may also explain why invertebrate larvae, in general, respond differently to different biofilms. The bacterial composition of the biofilm and the inductive capacities of the species present work together and are all significant factors in determining settlement induction. A better understanding of interactions between bacterial species and how they affect larval settlement is needed.

For coral species that require microbial cues to settle and metamorphose, there remain many questions to be investigated. Given that 3 strongly inductive bacterial species for settlement of coral larvae have been identified in this study, it is important to determine how they are represented in the field. Tracking the temporal variation of the 3 bacterial species may help determine when and where larvae recruit onto reefs and if settlement is affected by the dominance of a particular bacterial species at a given time. Further examination of the nature of the bacterial cue(s) that induce settlement will also be helpful, such as determining whether larvae would respond to a soluble water-borne compound or an insoluble surface-bound product. It is also essential to know the chemosensory mechanisms through which planulae perceive their external environment to detect settlement cues. Induction of metamorphosis is assumed to be mediated by receptors that detect the external cue(s) and activate a signal-transduction pathway that triggers metamorphosis. The cell types (presumed to be located in the aboral region of planulae; Vandermeulen 1974) that are involved in detecting and transducing such a signal must first be identified to comprehend the pathway itself. The present study offers some new insights into the induction of larval metamorphosis in a brooding coral, providing evidence that induction is dependent on very specific bacterial species that occur in natural marine biofilms. Understanding the types of bacteria that induce coral settlement and metamorphosis is an important step in understanding the complex process of coral recruitment.

Acknowledgements. We thank E. G. Ruby, M. Huggett, and Y. Huang for providing invaluable advice and discussion through the course of this work; P. L. Jokiel, K. Rodgers, C. Lager, and D. Lager for providing larvae for the latter portions of this research; B. Nedved for technical assistance; and 3 anonymous reviewers for constructive criticism of this manuscript. This research was supported by Office of Naval Research grant no. N00014-05-1-0579 to M.G.H., and an E. A. Kay Scholarship and Charles H. \& Margaret B. Edmondson Research Grant to C.T.

\section{LITERATURE CITED}

Arnold SN, Steneck RS, Mumby PJ (2010) Running the gauntlet: inhibitory effects of algal turfs on the processes of coral recruitment. Mar Ecol Prog Ser 414:91-105

- Baird AH, Morse ANC (2004) Induction of metamorphosis in larvae of the brooding corals Acropora palifera and Stylophora pistillata. Mar Freshw Res 55:469-472

Baird AH, Babcock RC, Mundy CR (2003) Habitat selection by larvae influences the depth distribution of six common coral species. Mar Ecol Prog Ser 252:289-293

Barott KL, Beltran R, Janouskovec J, Marhaver KL, Smith JE, Keeling P, Rohwer FL (2011) Microbial diversity associated with four functional groups of benthic reef algae and the reef-building coral Montastraea annularis. Environ Microbiol 13:1192-1204

Boettcher KJ, Ruby EG (1990) Depressed light emission by symbiotic Vibrio fisheri of the sepiolid squid Euprymna scolopes. J Bacteriol 172:3701-3706

Carlon DB, Olson RR (1993) Larval dispersal distance as an explanation for adult spatial pattern in two Caribbean reef corals. J Exp Mar Biol Ecol 173:247-263

> Costerton JW, Lewandowski Z, Caldwell DE, Korber DR, Lappin-Scott HM (1995) Microbial biofilms. Annu Rev Microbiol 49:711-745

Crisp DJ (1974) Factors influencing the settlement of marine invertebrate larvae. In: Grant PT, Mackie EM (eds) Chemoreception in marine organisms. Academic Press, New York, NY, p 177-265

Fleck J, Fitt WK (1999) Degrading mangrove leaves of Rhizophora mangle Linne provide a natural cue for settlement and metamorphosis of the upside down jellyfish Cassiopea xamachana Bigelow. J Exp Mar Biol Ecol 234: 83-94

Freeman G, Ridgway EB (1990) Cellular and intracellular pathways mediating the metamorphic stimulus in hydrozoan planulae. Rouxs Arch Dev Biol 196:30-50

Geyer CJ (1991) Markov Chain Monte Carlo maximum likelihood. In: Keramida EM (ed) Computing science and statistics. Proc 23rd Symp Interface. Interface Foundations, Fairfax Station, VA, p 156-163

Golbuu Y, Richmond RH (2007) Substratum preferences in planula larvae of two species of scleractinian corals, Goniastrea retiformis and Stylaraea punctata. Mar Biol 152: 639-644

Graham EM, Baird AH, Connolly SR (2008) Survival dynamics of scleractinian coral larvae and implications for dispersal. Coral Reefs 27:529-539

Hadfield MG (2000) Why and how marine invertebrate larvae metamorphose so fast. Semin Cell Dev Biol 11:437-443

Hadfield MG (2011) Biofilms and marine invertebrate larvae: what bacteria produce that larvae use to choose settlement sites. Annu Rev Mater Sci 3:453-470

Hadfield MG, Paul VJ (2001) Natural chemical cues for settlement and metamorphosis of marine invertebrate larvae. In: McClintock JB, Baker JB (eds) Marine chemical ecology. CRC, Boca Raton, FL, p 431-461

Hadfield MG, Carpizo-Ituarte EJ, del Carmen K, Nedved BT (2001) Metamorphic competence, a major adaptive convergence in marine invertebrate larvae. $J$ Zool 41: 1123-1131

Hall-Stoodley L, Costerton JW, Stoodley P (2004) Bacterial biofilms: from the natural environment to infectious diseases. Nat Rev Microbiol 2:95-108

Harrigan JF (1972) The planula larva of Pocillopora damicornis: lunar periodicity of swarming and substratum selection behavior. $\mathrm{PhD}$ dissertation, University of Hawaii at 
Manoa, Honolulu

Harrington L, Fabricius K, De'ath G, Negri AP (2004) Recognition and selection of settlement substrata determine post-settlement survival in corals. Ecology 85:3428-3437

- Harriott VJ (1983) Reproductive seasonality, settlement, and post-settlement mortality of Pocillopora damicornis (Linnaeus) at Lizard Island, Great Barrier Reef. Coral Reefs 2:151-157

$>$ Heyward AJ, Negri AP (1999) Natural inducers for coral larval metamorphosis. Coral Reefs 18:273-279

> Huang S, Hadfield MG (2003) Composition and density of bacterial biofilms determine larval settlement of the polychaete Hydroides elegans. Mar Ecol Prog Ser 260: 161-172

Huggett MJ, Williamson JE, de Nys R, Kjelleberg S, Steinberg PD (2006) Larval settlement of the common Australian sea urchin Heliocidaris erythrogramma in response to bacteria from the surface of coralline algae. Oecologia 149: 604-619

> Huelsenbeck JP, Ronquist F (2001) MRBAYES: Bayesian inference of phylogenetic trees. Bioinformatics 17: 754-755

> Johnson CR, Muir DG, Reysenbach AL (1991) Characteristic bacteria associated with surfaces of coralline algae: a hypothesis for bacterial induction of marine invertebrate larvae. Mar Ecol Prog Ser 74:281-294

Johnston IS, Rohwer F (2007) Microbial landscapes on the outer tissue surfaces of the reef building coral Porites compressa. Coral Reefs 26:375-383

Jokiel PL (1985) Lunar periodicity of planula release in the reef coral Pocillopora damicornis in relation to various environmental factors. Proc 5th Int Coral Reef Cong, Tahiti 4:307-312

Kitamura M, Koyama T, Nakano Y, Uemura D (2007) Characterization of a natural inducer of coral larval metamorphosis. J Exp Mar Biol Ecol 340:96-102

Miller K, Mundy C (2003) Rapid settlement in broadcast spawning corals: implications for larval dispersal. Coral Reefs 22:99-106

Morse DE, Hooker N, Morse ANC, Jensen RA (1988) Control of larval metamorphosis and recruitment in sympatric agariciid corals. J Exp Mar Biol Ecol 116:193-217

Morse ANC, Iwao K, Baba M, Shimoike K, Hayashibara T, Omori M (1996) An ancient chemosensory mechanism brings new life to coral reefs. Biol Bull 191:149-154

Müller WA (1973) Induction of metamorphosis by bacteria and ions in the planulae of Hydractinia echinata: an approach to the mode of action. Publ Seto Mar Biol Lab 20:195-208

Müller WA, Leitz T (2002) Metamorphosis in the Cnidaria. Can J Zool 80:1755-1771

Negri AP, Webster NS, Hill RT, Heyward AJ (2001) Metamorphosis of broadcast spawning corals in response to bacteria from crustose algae. Mar Ecol Prog Ser 223:121-131

Pasmore M, Costerton JW (2003) Biofilms, bacterial signaling, and their ties to marine biology. J Ind Microbiol Biotechnol 30:407-413

Price N (2010) Habitat selection, facilitation, and biotic settle-

Editorial responsibility: Charles Birkeland,

Honolulu, Hawaii, USA ment cues affect distribution and performance of coral recruits in French Polynesia. Oecologia 163:747-758

Richmond RH (1985) Reversible metamorphosis in coral planula larvae. Mar Ecol Prog Ser 22:181-185

Richmond RH (1987) Energetics, competency, and long-distance dispersal of planula larvae of the coral Pocillopora damicornis. Mar Biol 93:527-533

Richmond RH, Jokiel PL (1984) Lunar periodicity in larva release in the reef coral Pocillopora damicornis at Enewetak and Hawaii. Bull Mar Sci 34:280-287

Ritson-Williams R, Paul VJ, Arnold SN, Steneck RS (2010) Larval settlement preferences and post-settlement survival of the threatened Caribbean corals Acropora palmata and A. cervicornis. Coral Reefs 29:71-81

Seipp S, Schmich J, Kehrwald T, Leitz T (2007) Metamorphosis of Hydractinia echinata - natural versus artificial induction and developmental plasticity. Dev Genes Evol 217:385-394

Shikuma NJ, Hadfield MG (2006) Temporal variation of an initial marine biofilm community and effects on larval settlement and metamorphosis of the tubeworm Hydroides elegans. Biofilms 2:231-238

Shikuma NJ, Hadfield MG (2010) Marine biofilms on submerged surfaces are a reservoir for Escherichia coli and Vibrio cholerae. Biofouling 26:39-46

Stoodley P, Sauer K, Davies DG, Costerton JW (2002) Biofilms as complex differentiated communities. Annu Rev Microbiol 56:187-209

Swofford DL (2002) PAUP: Phylogenetic Analysis Using Parsimony, version 4.0b10. Sinauer Press, Sunderland, MA

Tamura K, Dudley J, Nei M, Kumar S (2007) MEGA4: Molecular Evolutionary Genetics Analysis (MEGA) software version 4.0. Mol Biol Evol 24:1596-1599

Unabia CRC, Hadfield MG (1999) Role of bacteria in larval settlement and metamorphosis of the polychaete Hydroides elegans. Mar Biol 133:55-64

Vandermeulen JH (1974) Studies on coral reefs. II. Fine structure of planktonic planula larva of Pocillopora damicornis, with emphasis on the aboral epidermis. Mar Biol 27: 239-249

> Webster NS, Smith LD, Heyward AJ, Watts JEM, Webb RI, Blackall LL, Negri AP (2004) Metamorphosis of a scleractinian coral in response to microbial biofilms. Appl Environ Microbiol 70:1213-1221

- Weisburg WG, Barns SM, Pelletier DA, Lane DJ (1991) 16S ribosomal DNA amplification for phylogenetic study. J Bacteriol 173:697-703

Wolfaardt GM, Lawrence JR, Korber DR (1999) Function of EPS. In: Wingender J, Neu TR, Flemming H (eds) Microbial extracellular polymeric substances: characterization, structure, and function. Springer, New York, NY, p 186-190

Zardus JD, Nedved BT, Huang Y, Tran C, Hadfield MG (2008) Microbial biofilms facilitate adhesion in biofouling invertebrates. Biol Bull 214:91-98

Zobell CE, Allen EC (1935) The significance of marine bacteria in the fouling of submerged surfaces. J Bacteriol 29: $239-251$

Submitted: December 10, 2010; Accepted: May 3, 2011

Proofs received from author(s): July 3, 2011 